\title{
Synthesis of Oligonucleotide Conjugates and Phosphorylated Nucleotide Analogues: An Improvement to a Solid Phase Synthetic Approach
}

\author{
Valeria Romanucci, Armando Zarrelli, Lorenzo De Napoli, \\ Cinzia Di Marino, and Giovanni Di Fabio \\ Department of Chemical Sciences, University of Napoli "Federico II", Via Cintia 4, 80126 Napoli, Italy \\ Correspondence should be addressed to Giovanni Di Fabio; difabio@unina.it
}

Received 13 January 2013; Revised 20 April 2013; Accepted 23 April 2013

Academic Editor: Alvaro Somoza

Copyright ( 2013 Valeria Romanucci et al. This is an open access article distributed under the Creative Commons Attribution License, which permits unrestricted use, distribution, and reproduction in any medium, provided the original work is properly cited.

\begin{abstract}
An improvement to our solid phase strategy to generate pharmacologically interesting molecule libraries is proposed here. The synthesis of new $o$-chlorophenol-functionalised solid supports with very high loading $(0.18-0.22 \mathrm{meq} / \mathrm{g}$ for control pore glass (CPG) and $0.25-0.50 \mathrm{meq} / \mathrm{g}$ for TG) is reported. To test the efficiency of these supports, we prepared nucleotide and oligonucleotide models, and their coupling yields and the purity of the crude detached materials were comparable to previously available results. These supports allow the facile and high-yield preparation of highly pure phosphodiester and phosphoramidate monoester nucleosides, conjugated oligonucleotides, and other yet unexplored classes of phosphodiester and phosphoramidate molecules.
\end{abstract}

\section{Introduction}

Oligonucleotides (ODNs) and nucleotides represent classes of potential therapeutic agents with a broad spectrum of pharmacological activities. Desired improvements of certain properties, such as cell-specific delivery, cellular uptake efficiency, intracellular distribution, and target specificity, can be achieved by chemical modifications. Conjugation of ODNs to other molecules (e.g., proteins and peptides, saccharides, fluorophores and photoprobes, inhibitors, and vitamins) that provide the conjugate with a desired novel property offers a feasible way to address these requirements [1-16]. With regard to nucleosides, however, many research groups have developed a prodrug approach to deliver biologically active nucleosides into cells in the form of masked charged monophosphate derivatives; a variety of different $5^{\prime}$-phosphorothioate and $5^{\prime}$-phosphodiester nucleoside analogues have been prepared for this purpose [17-21].

Organic chemists investigating these fields must prepare many types of pure modified compounds in sufficient quantities. The methods used for the preparation of these molecules fall into two major categories: solution and solid phase approaches. The solid phase method, in association with combinatorial chemistry approaches, has proven useful for the synthesis of a large number of these analogues. An advantage of the solid-supported method compared with conjugation or derivatisation in solution is that it is less laborious, among other advantages. In fact, on a solid support, the unreacted compounds are usually used in considerable excess, and the possible by-products can be removed by simple washing. The development of a broad array of reactions in the solid phase has increased the scope and potential of this method, allowing the synthesis of large libraries of compounds endowed with a diverse series of molecular motifs [26-29]. Various combinatorial approaches have been successfully adopted for the generation of a wide range of oligomeric and small molecule libraries for biological screens. Moreover, the combinatorial approach has allowed the rapid screening of a plethora of different substrates, accelerating lead identification and resulting in fundamental developments in biomedicinal chemistry. Within this framework, the low loading of the solid supports has proven to be a limitation of this method, as it strongly inhibits the amount of targets that can be obtained. 
Current solid phase methods for the synthesis of ODN conjugates include the utilisation of prefabricated labels, previously converted into the corresponding phosphoramidite or H-phosphonate derivatives, and elaborate supports bearing an appropriate linker to incorporate the conjugating residue, generally employed as a postsynthetic modification of the ODNs [30]. In both strategies, stringently applied purifications (in the first approach, for the reactive phosphorylated derivatives of the labels; in the second, for the preparation of the linker or in the final step) are typically required to isolate the desired conjugated molecule in a pure form [3134]. Although many methods have been reported for the solid phase synthesis of conjugated ODNs, the same cannot be said for solid phase synthesis of modified nucleotides. A variety of different $5^{\prime}$-phosphorylated, $5^{\prime}$-phosphoramidate, and $5^{\prime}$ phosphorothioate nucleoside analogues have been prepared and evaluated for their biological activity [17-21].

As part of our continuing effort towards the synthesis of new solid supports that are useful for generating pharmacologically interesting molecule libraries [22-25, 35-40] of high quality in large quantities, we present here an improvement of our solid phase strategy discussed above. Aiming to achieve the synthesis of a solid support with a higher load than that currently available and that is also compatible with phosphoramidite and phosphotriester chemistry, we devised a straightforward and efficient synthetic protocol to prepare a new support in which the loading of the $o$-chlorofunctional group is very high $(0.20-0.50 \mathrm{meq} / \mathrm{g})$.

\section{Experimental}

2.1. General. NMR spectra were recorded in $\mathrm{CDCl}_{3}$ and $\mathrm{CD}_{3} \mathrm{OD}$ with a Bruker WM 400 spectrometer. The chemical shifts $(\delta)$ are given in ppm and referenced to the residual solvent signal (7.26 and $3.31 \mathrm{ppm}$, resp.), and coupling con stants $(J)$ are in $\mathrm{Hz} .{ }^{31} \mathrm{P}$ NMR spectra were recorded at $161.98 \mathrm{MHz}$ using $\mathrm{D}_{3} \mathrm{PO}_{4}$ as an external standard. For ESIMS analysis, a Waters Micromass ZQ instrument-equipped with an electrospray source-was used in the negative mode. MALDI TOF mass spectrometric analyses were performed on a PerSeptive Biosystems Voyager-DE Pro MALDI mass spectrometer in the linear mode. HPLC analysis and purification were performed on an Agilent Technologies 1200 series instrument equipped with a UV detector. The crude materials of 5 and 6 were analysed by HPLC on a C18 Phenomenex LUNA column $(5 \mu \mathrm{m}, 10.0 \times 250 \mathrm{~mm})$ eluted with a linear gradient of $\mathrm{CH}_{3} \mathrm{CN}$ in $\mathrm{H}_{2} \mathrm{O}$, flow rate $=0.8 \mathrm{~mL} / \mathrm{min}$, and detection at $\lambda=260 \mathrm{~nm}$. The crude material of 9 was analysed by HPLC on a Nucleogel SAX column (MachereyNagel, 1000-8/46); buffer A: $20 \mathrm{mM} \mathrm{KH}_{2} \mathrm{PO}_{4}$ aq. solution, pH 7.0, containing 20\% (v/v) $\mathrm{CH}_{3} \mathrm{CN}$; buffer B: $1.0 \mathrm{M} \mathrm{KCl}$, $20 \mathrm{mM} \mathrm{KH}_{2} \mathrm{PO}_{4}$ aq. solution, $\mathrm{pH} \mathrm{7.0,} \mathrm{containing} \mathrm{20 \%} \mathrm{(v/v)}$ $\mathrm{CH}_{3} \mathrm{CN}$; linear gradient from 0 to $100 \% \mathrm{~B}$ over $30 \mathrm{~min}$, flow rate $0.8 \mathrm{~mL} / \mathrm{min}$, and detection at $\lambda=260 \mathrm{~nm}$. The crude material was purified by gel filtration chromatography on a Sephadex G25 column eluted with $\mathrm{H}_{2} \mathrm{O} / \mathrm{EtOH}(4: 1, \mathrm{v} / \mathrm{v})$. LCAA-CPG and TentaGel amino supports were purchased from Link Technologies and Novabiochem, respectively.
The nucleotide phosphoramidites, the activator solution $\left(0.45 \mathrm{M}\right.$ tetrazole in $\left.\mathrm{CH}_{3} \mathrm{CN}\right)$, and the oxidiser solution $\left(0.1 \mathrm{M} \mathrm{I}_{2} / \mathrm{THF} / \mathrm{H}_{2} \mathrm{O} /\right.$ pyridine $)$ were purchased from Link Technologies.

2.2. Synthesis of Supports $\mathbf{1 a}$ and $\mathbf{1 b}$. Support 1a: $250 \mathrm{mg}$ of LCAA-CPG-NH ${ }_{2}(0.10 \mathrm{meq} / \mathrm{g}, 0.02 \mathrm{mmol})$ was reacted, at r.t. overnight, with a mixture of $109.5 \mathrm{mg}(0.25 \mathrm{mmol})$ of $\mathrm{N}$ $\alpha$-Fmoc-3-chloro-L-tyrosine, $51.5 \mathrm{mg}(0.25 \mathrm{mmol})$ of DCCI, $45 \mu \mathrm{L}(0.25 \mathrm{mmol})$ of DIEA, and $38.0 \mathrm{mg}(0.25 \mathrm{mmol})$ of $\mathrm{N}$-hydroxybenzotriazole $\left(\mathrm{HOBt} \cdot \mathrm{H}_{2} \mathrm{O}\right)$ dissolved in $3 \mathrm{~mL}$ of anhydrous pyridine. After exhaustive washing with DCM and $\mathrm{Et}_{2} \mathrm{O}$, the support was dried under reduced pressure and then treated with $20 \%$ piperidine in DMF three times for $5 \mathrm{~min}$. The coupling and Fmoc removal were repeated twice more in similar conditions. According to the Kaiser test [41], the incorporation of the linker was always in the range of 65$85 \%$, corresponding to $0.19-0.25 \mathrm{meq} / \mathrm{g}$. After capping the unreacted amino functional groups with $\mathrm{Ac}_{2} \mathrm{O}$ /pyridine $(1: 1$, $\mathrm{v} / \mathrm{v})$ for $1 \mathrm{~h}$ at r.t., the support was treated with conc. aq. ammonia $(28 \%)$ at $50^{\circ} \mathrm{C}$ for $1 \mathrm{~h}$. After exhaustive washing with $\mathrm{CH}_{3} \mathrm{OH}, \mathrm{DCM}$, and $\mathrm{Et}_{2} \mathrm{O}$, the resulting support la was dried under reduced pressure.

Support 1b: $250 \mathrm{mg}$ of TG-NH $\mathrm{NH}_{2}$ LL $(0.29 \mathrm{meq} / \mathrm{g}, 0.07$ $\mathrm{mmol})$ was reacted, at r.t. overnight, with a mixture of 317.5 $\mathrm{mg}(0.72 \mathrm{mmol})$ of $\mathrm{N}-3$-chlorotyrosine acid, $150.0 \mathrm{mg}(0.72$ $\mathrm{mmol})$ of DCCI, $126.0 \mu \mathrm{L}$ of DIEA, and $110.0 \mathrm{mg}(1.5 \mathrm{mmol})$ of N-hydroxybenzotriazole $\left(\mathrm{HOBt} \cdot \mathrm{H}_{2} \mathrm{O}\right)$ dissolved in $5 \mathrm{~mL}$ of anhydrous pyridine. After exhaustive washing with DCM and $\mathrm{Et}_{2} \mathrm{O}$, the support was dried under reduced pressure and then treated with $20 \%$ piperidine in DMF three times for $5 \mathrm{~min}$. The coupling and Fmoc removal were repeated twice more in similar conditions. The incorporation of the linker was always in the range of $65-85 \%$, corresponding to $0.50-0.75 \mathrm{meq} / \mathrm{g}$, according to the Kaiser and Fmoc tests. After capping the unreacted amino functional groups with $\mathrm{Ac}_{2} \mathrm{O} /$ pyridine $(1: 1$, $\mathrm{v} / \mathrm{v}$ ) for $1 \mathrm{~h}$ at r.t., the support was treated with conc. aq. ammonia $(28 \%)$ at $50^{\circ} \mathrm{C}$ for $1 \mathrm{~h}$. After exhaustive washing with $\mathrm{CH}_{3} \mathrm{OH}, \mathrm{DCM}$, and $\mathrm{Et}_{2} \mathrm{O}$, the resulting support $\mathbf{1 b}$ was dried under reduced pressure.

2.3. Synthesis of Supports $\mathbf{4 a}, \mathbf{4 b}$, and $\mathbf{8 a}$. Support $\mathbf{4 a}$ : $1.1 \mathrm{~mL}$ $(0.5 \mathrm{mmol})$ of a commonly used "activator solution" $(0.45$ $\mathrm{M}$ tetrazole in $\left.\mathrm{CH}_{3} \mathrm{CN}\right)$ was added to $0.08 \mathrm{mmol}$ of $5^{\prime}-\mathrm{O}-(2-$ cyanoethyl)-N,N-diisopropylphosphoramidite-3' -O-(4,4'-didimethoxytriphenylmethyl)-thymidine, and $250 \mathrm{mg}(0.22$ $\mathrm{meq} / \mathrm{g}, 0.05 \mathrm{mmol}$ ) of support 1a. After $1 \mathrm{~h}$, the support was exhaustively washed with $\mathrm{CH}_{3} \mathrm{CN}$ and treated (3 times) with $5 \mathrm{~mL}$ of a commonly used "oxidiser" solution $\left(\mathrm{I}_{2} /\right.$ pyridine $/ \mathrm{H}_{2} \mathrm{O} / \mathrm{THF}$ ) for $5 \mathrm{~min}$. After exhaustive washing with $\mathrm{CH}_{3} \mathrm{CN}, \mathrm{DCM}$, and $\mathrm{Et}_{2} \mathrm{O}$, the resulting support 3a was dried under reduced pressure. Incorporation yields of the nucleotides were always in the range of $82-99 \%$ $(0.18-0.22 \mathrm{meq} / \mathrm{g})$, as determined by a quantitative DMT test performed on dried and weighed samples of support $3 \mathbf{a}$. After the standard capping procedure with $\mathrm{Ac}_{2} \mathrm{O} /$ pyridine $(1: 1, \mathrm{v} / \mathrm{v})$, the 2-cyanoethyl group from the phosphate was 
then removed by treatment with $20 \%$ piperidine in DMF for $5 \mathrm{~min}$ at r.t. (3 times), resulting in support 4 a.

Support 4b: $4.9 \mathrm{~mL}(2.2 \mathrm{mmol})$ of a commonly used "activator solution" ( $0.45 \mathrm{M}$ tetrazole in $\left.\mathrm{CH}_{3} \mathrm{CN}\right)$ was added to $0.35 \mathrm{mmol}$ of the $5^{\prime}-\mathrm{O}$-(2-cyanoethyl)-N,N-diisopropylphosphoramidite-3'-O-(4,4'-dimethoxytriphenylmethyl)$2^{\prime}$-deoxyribonucleoside, and $250 \mathrm{mg}$ ( $\left.0.55 \mathrm{meq} / \mathrm{g}, 0.14 \mathrm{mmol}\right)$ of support $\mathbf{1 b}$. After $1 \mathrm{~h}$, the support was exhaustively washed with $\mathrm{CH}_{3} \mathrm{CN}$ and treated (5 times) with $5 \mathrm{~mL}$ of a commonly used "oxidiser" solution $\left(\mathrm{I}_{2} /\right.$ pyridine $/ \mathrm{H}_{2} \mathrm{O} / \mathrm{THF}$ ) for $5 \mathrm{~min}$. After exhaustive washing with $\mathrm{CH}_{3} \mathrm{CN}, \mathrm{DCM}$, and $\mathrm{Et}_{2} \mathrm{O}$, the resulting support was dried under reduced pressure. The complete oxidation of the phosphite triester into a phosphate triester, leading to support $\mathbf{3 b}$, was monitored by ${ }^{31} \mathrm{P}$ NMR of the resin suspended in $\mathrm{CDCl}_{3}$. As is typical, a relevant upfield shift of the signal at $137 \mathrm{ppm}$ to two signals centred at $\delta-6.5 \mathrm{ppm}$ was observed. After a standard capping procedure with $\mathrm{Ac}_{2} \mathrm{O} /$ pyridine $(1: 1, \mathrm{v} / \mathrm{v})$, the 2-cyanoethyl group was removed from the phosphate by treatment with $20 \%$ piperidine in DMF for 5 min at r.t. (5 times), resulting in support $\mathbf{4 b}$. Incorporation yields of nucleotides, calculated after capping, were always in the range of $75-91 \%(0.40-$ $0.50 \mathrm{meq} / \mathrm{g}$ ), as determined by a quantitative DMT test performed on dried and weighed samples of support $\mathbf{4 b}$. The total deprotection of the phosphates was confirmed by a characteristic upfield shift in the signal of the ${ }^{31} \mathrm{P} N M R$ spectrum of the solid support suspended in $\mathrm{CDCl}_{3}$.

Support 8a: this support was obtained by following the procedure described for the synthesis of support 4a, using 5'-O-(4,4'-dimethoxytriphenylmethyl)-3'-O-(2-cyanoethyl)$\mathrm{N}, \mathrm{N}$-diisopropylphosphoramidite-thymidine starting from support la.

2.4. Synthesis of Thymidine Analogue 5. $30 \mathrm{mg}(0.40 \mathrm{meq} / \mathrm{g}$, $0.012 \mathrm{mmol}$ ) of dried support $\mathbf{4} \mathbf{b}$ was washed and swelled in anhydrous pyridine and then reacted with a mixture of $46 \mathrm{mg}(0.12 \mathrm{mmol})$ of cholesterol and $36 \mathrm{mg}(0.12 \mathrm{mmol})$ of MSNT in $500 \mu \mathrm{L}$ of anhydrous pyridine for $12 \mathrm{~h}$ at r.t. After exhaustive washing with pyridine, $\mathrm{CH}_{3} \mathrm{OH}, \mathrm{DCM}$, and $\mathrm{Et}_{2} \mathrm{O}$, the target analogues were detached from the support by conc. aq. ammonia treatment at $50^{\circ} \mathrm{C}$ for $5 \mathrm{~h}$. The crude material of 5 was analysed by HPLC on a C18 Phenomenex LUNA column $(5 \mu \mathrm{m}, 10.0 \times 250 \mathrm{~mm})$ eluted with a linear gradient (from 10 to $100 \% \mathrm{~B}$ over $30 \mathrm{~min}, \mathrm{~A}=\mathrm{H}_{2} \mathrm{O}, \mathrm{B}=\mathrm{CH}_{3} \mathrm{CN}$ ), flow rate $=0.8 \mathrm{~mL} / \mathrm{min}$, detection at $\lambda=260 \mathrm{~nm}, t_{R}=16.5 \mathrm{~min}$, and HPLC purity $88 \%$ (see Figure 1 ). ${ }^{1} \mathrm{H}$ NMR $\left(\mathrm{CD}_{3} \mathrm{OD}\right.$, $400 \mathrm{MHz}) \delta: 7.79(1 \mathrm{H}, \mathrm{s}, \mathrm{H}-6 \mathrm{~T}), 6.35(1 \mathrm{H}, \mathrm{dd}, J=6.4,6.4 \mathrm{~Hz}$, $\left.\mathrm{H}-1^{\prime} \mathrm{T}\right), 5.32(1 \mathrm{H}, \mathrm{m}, \mathrm{H}-6$ cholesterol residue), $4.50(1 \mathrm{H}, \mathrm{m}$, $\left.\mathrm{H}-3^{\prime} \mathrm{T}\right), 4.04-3.90$ (3H, overlapped signals, $\mathrm{H}-4^{\prime}$, and $\mathrm{H}_{2}-5^{\prime}$ $\mathrm{T}), 3.65(1 \mathrm{H}, \mathrm{s}, \mathrm{H}-3$ cholesterol residue $), 2.30\left(2 \mathrm{H}, \mathrm{m}, \mathrm{H}_{2}-2^{\prime}\right.$ T), 2.20-0.65 (complex signals of cholesterol residue), and $1.94\left(3 \mathrm{H}, \mathrm{s}, \mathrm{CH}_{3} \mathrm{~T}\right) \mathrm{ppm} .{ }^{31} \mathrm{P} \mathrm{NMR}\left(\mathrm{CD}_{3} \mathrm{OD}, 161.98 \mathrm{MHz}\right)$ $\delta: 2.6 \mathrm{ppm}$. ESI-MS $m / z: 688.51\left[(\mathrm{M}-\mathrm{H})^{-}\right]$.

2.5. Synthesis of Thymidine Analogue 6. Synthesis of $\mathbf{6}$ starting from $4 \mathrm{a}: 50 \mathrm{mg}(0.22 \mathrm{meq} / \mathrm{g}, 0.011 \mathrm{mmol})$ of dried support 4a was washed and swelled in anhydrous pyridine. The support was then treated with $1 \mathrm{~mL}$ of a freshly prepared

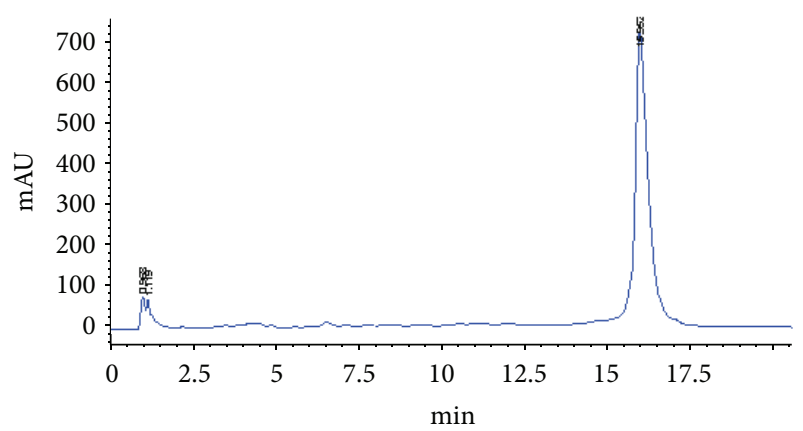

FIGURE 1: SAX-HPLC profile of crude detached 5 (Phenomenex LUNA, $5 \mu \mathrm{m} \mathrm{C18}, 10.0 \times 250 \mathrm{~mm}$ ) eluted with a linear gradient from 10 to $100 \% \mathrm{~B}$ in $30 \mathrm{~min}, \mathrm{~A}=\mathrm{H}_{2} \mathrm{O}, \mathrm{B}=\mathrm{CH}_{3} \mathrm{CN}$; detection at $\lambda=$ $260 \mathrm{~nm}$; flow rate $0.8 \mathrm{~mL} / \mathrm{min}$.

tosyl chloride solution ( $0.2 \mathrm{M} \mathrm{TsCl}, 0.4 \mathrm{M}$ NMIm in pyridine) for $15 \mathrm{~min}$ at r.t. to generate the active ester, followed by addition of $1 \mathrm{~mL}$ of the amine solution $(0.45 \mathrm{M}$ in pyridine), with appropriate washing steps in between [42]. This procedure was repeated six times. After exhaustive washing with pyridine, $\mathrm{CH}_{3} \mathrm{OH}, \mathrm{DCM}$, and $\mathrm{Et}_{2} \mathrm{O}$, the resulting support was dried under reduced pressure. The conjugation yields were evaluated by the DMT cation test on a weighed sample of the support after ammonia treatment $\left(28 \% \mathrm{NH}_{4} \mathrm{OH}, 50^{\circ} \mathrm{C}\right.$, $5 \mathrm{~h}$ ). The conjugation yields were always in the range of $65-$ $75 \%$. The target analogue 6 was detached from the support by conc. aq. ammonia treatment at $50^{\circ} \mathrm{C}$ for $5 \mathrm{~h}$. The crude material was analysed by HPLC on a C18 Phenomenex LUNA column $(5 \mu \mathrm{m}, 10.0 \times 250 \mathrm{~mm})$ eluted with a linear gradient (from 0 to $100 \% \mathrm{~B}$ over $30 \mathrm{~min}, \mathrm{~A}=\mathrm{H}_{2} \mathrm{O}, \mathrm{B}=\mathrm{CH}_{3} \mathrm{CN}$ ), flow rate $=0.8 \mathrm{~mL} / \mathrm{min}$, detection at $\lambda=260 \mathrm{~nm}, t_{R}=13.6 \mathrm{~min}$, and HPLC purity $91 \%$.

Synthesis of $\mathbf{6}$ starting from $\mathbf{4 b}$ : $30 \mathrm{mg}(0.40 \mathrm{meq} / \mathrm{g}$, $0.012 \mathrm{mmol}$ ) of dried support $\mathbf{4 b}$ was washed and swelled in anhydrous pyridine. The support was then treated with $2 \mathrm{~mL}$ of a freshly prepared tosyl chloride solution $(0.2 \mathrm{M}$ $\mathrm{TsCl}, 0.4 \mathrm{M}$ NMIm in pyridine) for $15 \mathrm{~min}$ at r.t. to generate the active ester, followed by the addition of $1 \mathrm{~mL}$ of the butylamine solution ( $0.45 \mathrm{M}$ in pyridine), with appropriate washing steps in between. This procedure was repeated ten times. After exhaustive washings with pyridine, $\mathrm{CH}_{3} \mathrm{OH}$, $\mathrm{DCM}$, and $\mathrm{Et}_{2} \mathrm{O}$, the resulting support was dried under reduced pressure. The conjugation yields were evaluated by the DMT cation test on a weighed sample of the support after ammonia treatment $\left(28 \% \mathrm{NH}_{4} \mathrm{OH}, 50^{\circ} \mathrm{C}, 5 \mathrm{~h}\right)$. The conjugation yields were always in the range of $85-90 \%$. The target analogue $\mathbf{6}$ was detached from the support by conc. aq. ammonia treatment at $50^{\circ} \mathrm{C}$ for $5 \mathrm{~h}$. The crude material was analysed by HPLC on a C18 Phenomenex LUNA column $(5 \mu \mathrm{m}, 10.0 \times 250 \mathrm{~mm})$ eluted with a linear gradient (from 0 to $100 \% \mathrm{~B}$ over $30 \mathrm{~min}, \mathrm{~A}=\mathrm{H}_{2} \mathrm{O}, \mathrm{B}=\mathrm{CH}_{3} \mathrm{CN}$ ), flow rate $=0.8 \mathrm{~mL} / \mathrm{min}$, detection at $\lambda=260 \mathrm{~nm}, t_{R}=13.6 \mathrm{~min}$, and HPLC purity $86 \% .{ }^{1} \mathrm{H}$ NMR $\left(\mathrm{CD}_{3} \mathrm{OD}, 400 \mathrm{MHz}\right) \delta: 7.89(1 \mathrm{H}$, s, H-6 T), $6.35\left(1 \mathrm{H}, \mathrm{dd}, J=6.4,6.4 \mathrm{~Hz}, \mathrm{H}-1^{\prime} \mathrm{T}\right), 4.52(1 \mathrm{H}, \mathrm{m}, \mathrm{H}-$ $\left.3^{\prime} \mathrm{T}\right), 4.03\left(1 \mathrm{H}, \mathrm{bs}, \mathrm{H}-4^{\prime} \mathrm{T}\right), 3.96\left(2 \mathrm{H}, \mathrm{bs}, \mathrm{H}_{2}-5^{\prime} \mathrm{T}\right), 2.86(2 \mathrm{H}$, $\left.\mathrm{m}, \mathrm{CH}_{2}-\mathrm{NH}\right), 2.33-2.18\left(2 \mathrm{H}, \mathrm{m}, \mathrm{H}_{2}-2^{\prime} \mathrm{T}\right), 1.95\left(3 \mathrm{H}, \mathrm{s}, \mathrm{CH}_{3} \mathrm{~T}\right)$, 


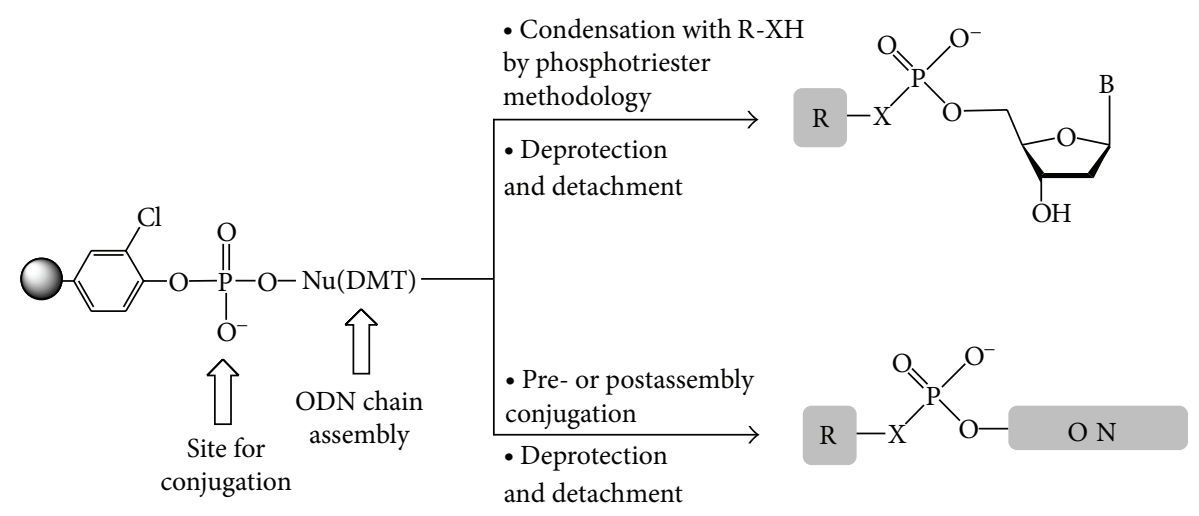

$\mathrm{Nu}(\mathrm{ODMT})=5^{\prime}$-ODMT- $3^{\prime}$-phosphoramidite-nucleoside $\quad \mathrm{X}=\mathrm{O}, \mathrm{NH} \quad \mathrm{R} \quad=$ labeling group or $5^{\prime}$-phosphoramidite-3'-ODMT-nucleoside

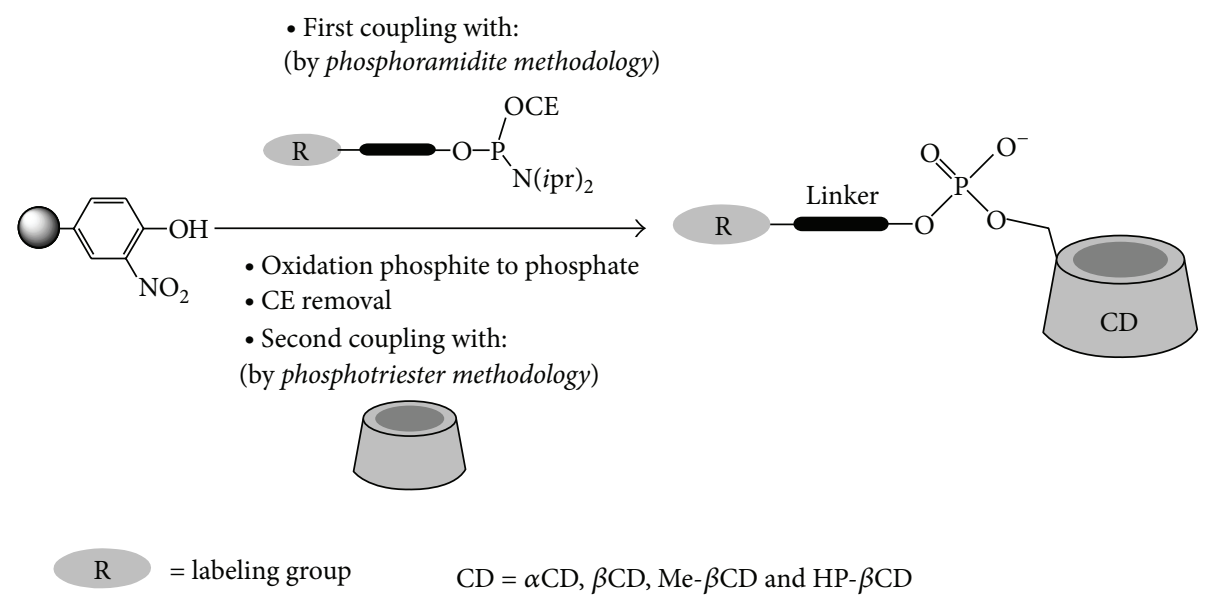

Scheme 1: Solid phase methodology to obtain phosphodiester, phosphoramidate monoester nucleoside analogues [22], oligonucleotide conjugates [23, 24], and monofunctionalised CDs [25].

$1.46\left(2 \mathrm{H}, \mathrm{m}, \mathrm{CH}_{3}-\mathrm{CH}_{2}-\mathrm{CH}_{2}-\mathrm{CH}_{2}-\mathrm{NH}\right), 1.32\left(2 \mathrm{H}, \mathrm{m}, \mathrm{CH}_{3}-\right.$ $\left.\mathrm{CH}_{2}-\mathrm{CH}_{2}-\mathrm{CH}_{2}-\mathrm{NH}\right)$, and $0.89\left(3 \mathrm{H}, \mathrm{t}, J=7.2 \mathrm{~Hz}, \mathrm{CH}_{3}\right.$ butyl residue) ppm. ${ }^{31} \mathrm{P}$ NMR $\left(\mathrm{CD}_{3} \mathrm{OD}, 161.98 \mathrm{MHz}\right) \delta: 11.0 \mathrm{ppm}$. ESI-MS $m / z: 376.24\left[(\mathrm{M}-\mathrm{H})^{-}\right]$.

2.6. Synthesis of Oligonucleotide Conjugated 9. $50 \mathrm{mg}$ $(0.22 \mathrm{meq} / \mathrm{g}, 0.011 \mathrm{mmol})$ of dried support $8 \mathbf{a}$ was washed and swelled in anhydrous pyridine. The support was then treated with $1 \mathrm{~mL}$ of a freshly prepared tosyl chloride solution (0.2 M TsCl, 0.4 M NMIm in pyridine) for $15 \mathrm{~min}$ at r.t. to generate the active ester, followed by the addition of $1 \mathrm{~mL}$ of the butylamine solution $(0.45 \mathrm{M}$ in pyridine), with appropriate washing steps in between. This procedure was repeated six times. After exhaustive washings with pyridine, $\mathrm{CH}_{3} \mathrm{OH}, \mathrm{DCM}$, and $\mathrm{Et}_{2} \mathrm{O}$, the resulting support was dried under reduced pressure. Starting from $25 \mathrm{mg}$ of support, a 10-mer oligodeoxyribonucleotide was assembled by the automated standard phosphoramidite procedure [43] (DMT off), using commercially available phosphoramidite nucleosides. Detachment from the support and deprotection were achieved by treatment with conc. aq. ammonia solution $\left(28 \%, 6 \mathrm{~h}, 55^{\circ} \mathrm{C}\right)$, and the crude material, thus, released was then purified by a simple gel filtration chromatography on a Sephadex G25 column eluted with $\mathrm{H}_{2} \mathrm{O} / \mathrm{EtOH}(4: 1, \mathrm{v} / \mathrm{v})$. The purity of the isolated compounds was then checked by ion exchange HPLC analysis and their identities determined by MALDI-TOF mass spectrometry $t_{R}=31.2 \mathrm{~min}$. MALDI-TOF $m / z: 3040.63\left[(\mathrm{M}-\mathrm{H})^{+}\right]$(obsv.), 3038.55 (calcd.).

\section{Results and Discussion}

3.1. Synthesis of Supports following the New Strategy. We have recently reported a simple solid phase methodology to obtain phosphodiester and phosphoramidate monoester nucleoside analogues and $5^{\prime}$ - and $3^{\prime}$-ODN conjugates in extremely pure form by using standard phosphotriester chemistry (Scheme 1). Initially, inspired by Pedroso's procedure previously developed for the solid phase synthesis of cyclic ODNs [36], we prepared a small library of thymidine analogues conjugated at the $5^{\prime}$-position with a set of representative 


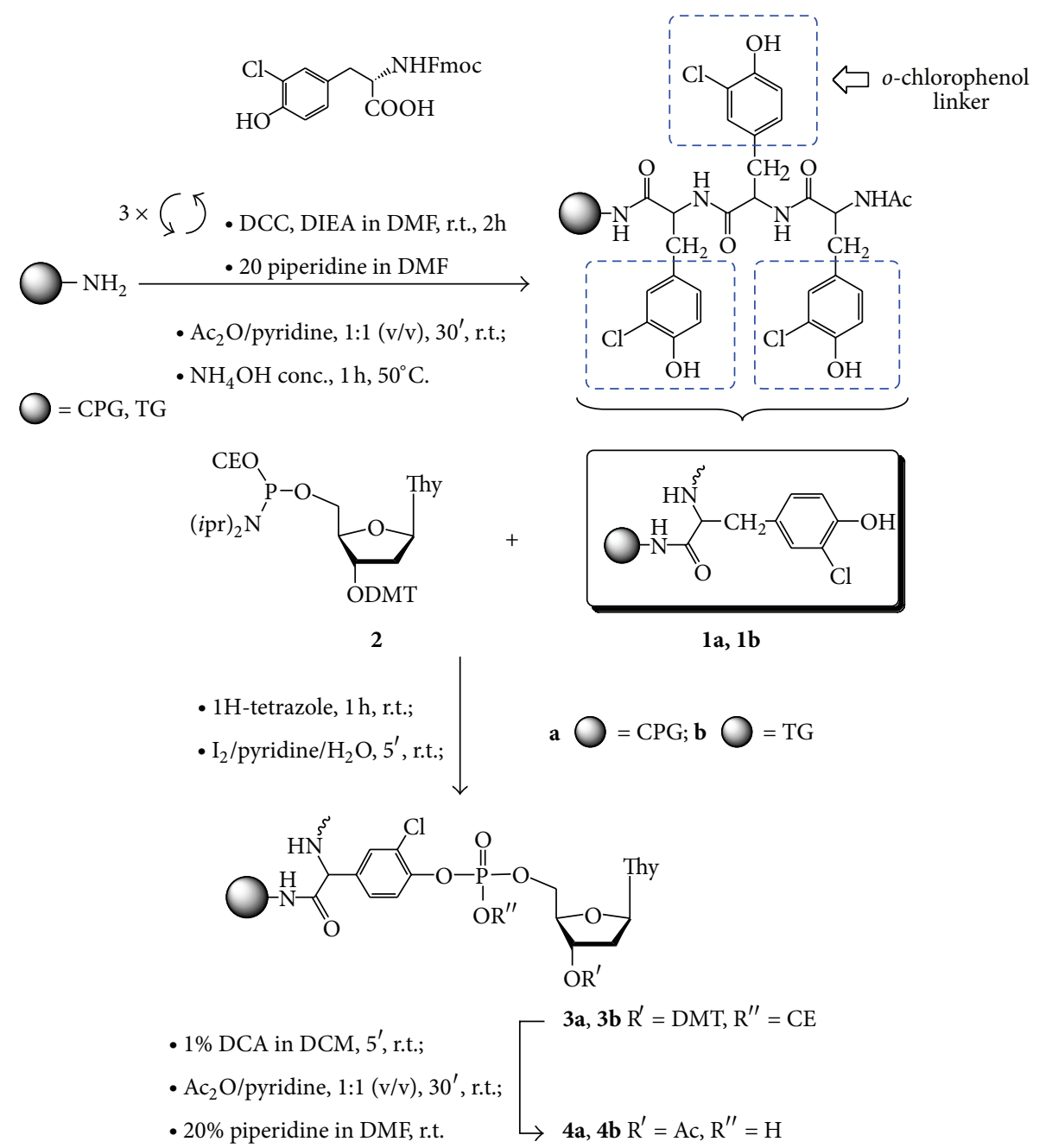

Scheme 2: The strategy to obtain CPG or TG with high loading of $o$-chlorophenol residues.

alcohols and amines [22]. Later, a number of $5^{\prime}$ - or $3^{\prime}$ ODN and $3^{\prime}$-oligoribonucleotide conjugates, incorporating a variety of labels covalently linked through a phosphodiester or a phosphoramidate bond, were synthesised and characterised [23, 24, 37]. In all cases, ad hoc derivatised solid supports, to which the first nucleoside unit was attached through a phosphate linkage, have been exploited (Scheme 1). The key step in our strategy is the derivatisation of the solid support (TG, CPG) with a 3-chloro-4-hydroxyphenylacetic linker, onto which the nucleotide is attached through a phosphate triester linkage. Due to the structure of the linker, after cleavage from the support, the HPLC analyses of the released nucleotides and ODNs showed only the single desired product in all cases. High purity can be obtained because only the nucleoside or ODN linked to the support through a phosphotriester or phosphoramidate diester bond is cleaved from the resin after ammonia treatment, whereas the nucleoside or ODN anchored through a phosphodiester bond, that is, the unreacted ODN chain, is not affected under the same conditions.

Recently, this approach was extended to the regioselective solid phase synthesis of cyclodextrins (CDs) tethered to a variety of labels through a stable phosphodiester linkage at the C-6 position (Scheme 1) [25]. The new support, based on the Novagel resin anchored with an $o$-nitrophenol linker $(0.46 \mathrm{meq} / \mathrm{g})$, allowed the detachment of the desired products under conditions milder than those required for the support with the $o$-chlorophenol linker. These results have shown that anchoring the $o$-chloro- or $o$-nitrophenol linker to a suitable matrix allows us to extend our methodology to all molecules whose phosphoramidites are either commercially available or easily realised through standard, recognised chemistry.

To exploit the advantages of the regioselective release of the $o$-chlorophenol support, here, we report the synthesis of a support derivatised with an $o$-chlorophenol linker that shows higher loading than those previously reported and is useful for large scale syntheses. The key step was the derivatisation of commonly used (LCAA-CPG and TG) solid supports with $\mathrm{N}$ $\alpha$-Fmoc-3-chloro-L-tyrosine (3-Cl-Tyr). Unlike the 3-chloro4-hydroxy-phenylacetic linker, used previously, the 3-chloroL-tyrosine linker not only contains an $o$-chlorophenol skeleton but also simultaneously has amino and acidic functional groups, which allow a versatile elongation of the peptide chain, with a resulting increase of the functionalisation of 

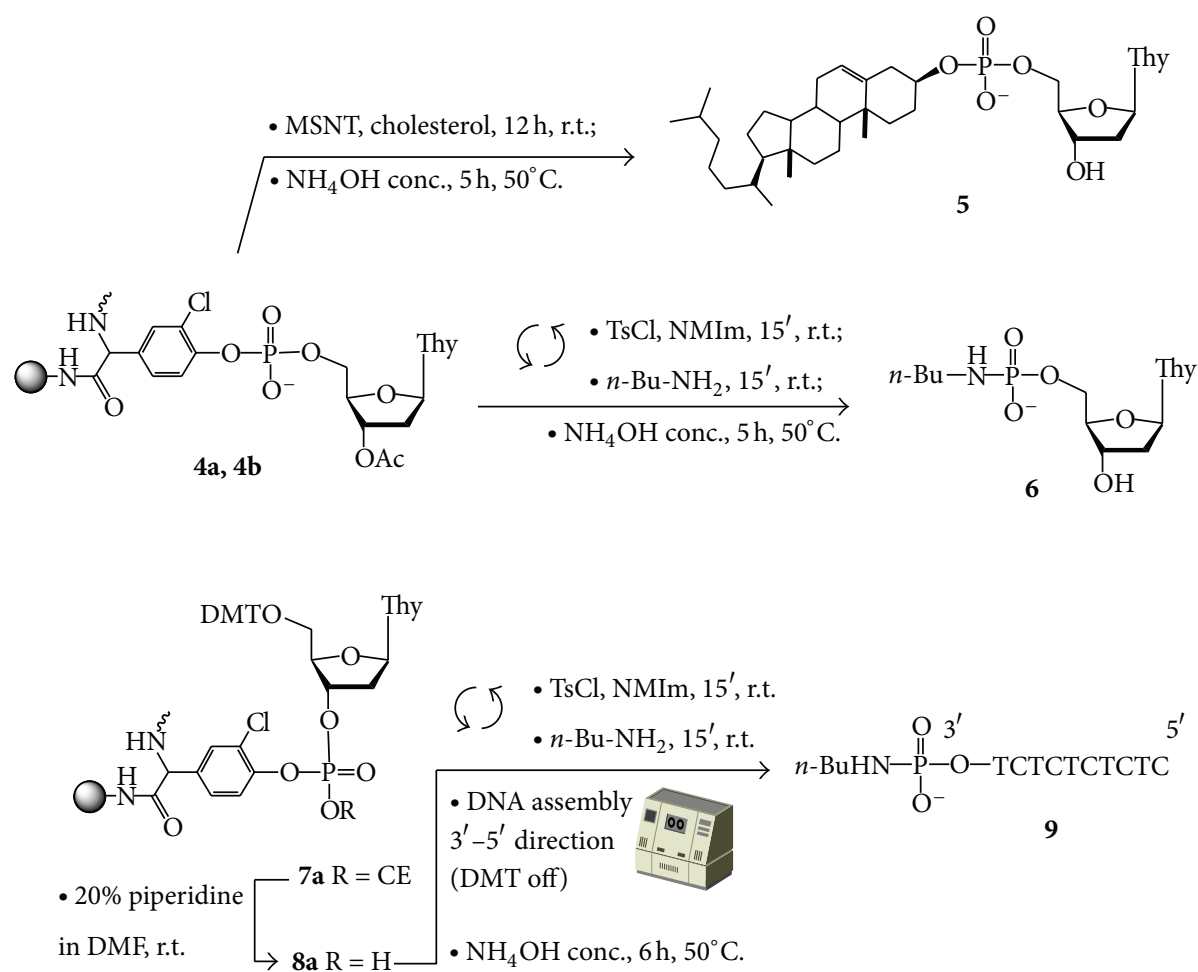

Scheme 3: The feasibility tests of new supports for the solid phase synthesis of nucleotide analogues and oligonucleotide conjugates.

the $\mathrm{OH}$ groups. In an initial series of experiments, we synthesised supports (LCAA-CPG (load $0.10 \mathrm{meq} / \mathrm{g}$ ) or TG (load $0.29 \mathrm{meq} / \mathrm{g}$ ) amino supports) with a homopeptide (3$\mathrm{Cl})-\mathrm{Tyr}_{3}$ following an Fmoc protocol, leading to $\mathbf{l a}$ and $\mathbf{1 b}$, respectively (Scheme 2). The peptide chain was prepared using DCC/HOBt as coupling agents, with each monomer addition monitored by the Kaiser test; the yields were always in the range of $65-85 \%$, corresponding to $0.19-0.25 \mathrm{meq} / \mathrm{g}$ for $\mathbf{l a}$ and $0.50-0.75 \mathrm{meq} / \mathrm{g}$ for $\mathbf{1 b}$.

To test the efficiency of these supports in the synthesis of phosphodiester and phosphoramidate monoester nucleoside analogues, we followed two different methods, as previously reported. In preliminary tests, we chose to synthesise the cholesteryl phosphodiester and butylamino phosphoramidate of thymidine as nucleotide models. Initially, the $5^{\prime}$-phosphoramidite thymidine derivative 2 was anchored to matrices (CPG and TG) by exploiting classical phosphoramidite chemistry. After conversion of the phosphite to phosphate triesters, affording supports $\mathbf{3} \mathbf{a}$ and $\mathbf{3} \mathbf{b}$, the incorporation of the nucleotide, as determined by the DMT test, was always in the range of $0.18-0.22 \mathrm{meq} / \mathrm{g}$ for LCAACPG (3a) and $0.25-0.50 \mathrm{meq} / \mathrm{g}$ starting from a TG amino resin (3b). Compared with our previous work, here we have doubled resin loading (0.08-0.10 meq/g and 0.19-0.22 meq/g, resp.).

To obtain the phosphodiester thymidine derivative $\mathbf{5}$ (Scheme 3), support $\mathbf{4 b}$ was reacted with MSNT and cholesterol in pyridine at r.t. for $12 \mathrm{~h}$. To prepare the phosphoramidate thymidine derivative, support $4 \mathbf{a}$ was treated three times with $p$-tosyl chloride in pyridine and then reacted with the butylamine dissolved in pyridine. As expected, the conjugation efficiency was always in the range of $70-80 \%$, leading to supports with $0.13-0.18 \mathrm{meq} / \mathrm{g}$ and $0.18-0.40 \mathrm{meq} / \mathrm{g}$ loading for $\mathbf{4 a}$ and $\mathbf{4 b}$, respectively. These yields could be indirectly evaluated by DMT tests on weighed samples of the support after ammonia treatment, determining the amount of unconjugated material left on the solid support. In fact, only nucleosides linked to the support through a phosphotriester or phosphoramidate diester linkage are easily removed upon basic treatment $\left(28 \% \mathrm{NH}_{4} \mathrm{OH}, 50^{\circ} \mathrm{C}, 5 \mathrm{~h}\right)$, whereas nucleosides anchored through a phosphodiester bond are not cleaved from the resin under the same conditions. After DMT removal and detachment from the supports, the obtained crude material was analysed by RP-HPLC, and the profiles showed a single major peak with an area (85\%-91\%) similar to values reported previously (Figure 1). The identity of 5 and 6 was determined by ${ }^{1} \mathrm{H},{ }^{31} \mathrm{P}$ NMR, and ESI-MS experiments that were conducted directly on the crude detached material. As expected, starting from $30 \mathrm{mg}$ of support $\mathbf{4 a}$ or $\mathbf{4 b}$, the target nucleotides were recovered as discrete compounds in 2-4 $\mathrm{mg}$ and 4-9 mg quantities, respectively, in a highly pure form.

To demonstrate the reliability of the CPG supports for the automatic synthesis of ODNs, automated assembly has been explored for the synthesis of the ODN chains, adopting the elongation directions $\left(3^{\prime}-5^{\prime}\right)$. Starting from support 8a, a 10mer was synthesised (Scheme 3 ), and after ammonia cleavage and deprotection $\left(6 \mathrm{~h}, 50^{\circ} \mathrm{C}\right)$, ion exchange HPLC analysis of the released $\mathrm{ODN}$ showed a single product corresponding to the desired compound 9 . The purity of the isolated compound 
was then checked by HPLC, and its identity was determined by MALDI-TOF MS analysis. In a typical experiment, starting from $35 \mathrm{mg}$ of functionalised support $\mathbf{8 a}$ with an average $0.15 \mathrm{meq} / \mathrm{g}$ incorporation of the conjugating residue, $150-200$ OD units of pure ODNs were isolated after gel filtration.

\section{Conclusions}

In conclusion, we have reported the synthesis of a new $o$-chlorophenol-functionalised solid support, characterised by a higher loading of hydroxyl phenol functions than previously achievable $(0.18-0.22 \mathrm{meq} / \mathrm{g}$ to $\mathrm{CPG}$ and $0.25-$ $0.50 \mathrm{meq} / \mathrm{g}$ to TG). This support allows the facile and highyield preparation of phosphodiester and phosphoramidate monoester nucleosides, as well as other yet unexplored classes of phosphodiester and phosphoramidate molecules. To test the efficiency of this support, we prepared model thymidine analogues conjugated at the $5^{\prime}$-position to cholesterol and n-butylamine through phosphodiester and phosphoramidate bridges, respectively. In all cases, the coupling yields and purity of crude detached materials were comparable to our previous results, and twice as much target was obtained, due to the loading being doubled on average. Based on these preliminary studies, the method is efficient and very reliable. This synthetic approach proposed here can be a starting point for the development of a preparative method for obtaining new phosphodiester and phosphoramidate nucleotides and oligonucleotide conjugates. Further studies are currently in progress to optimise the yields of 3-chloro-L-tyrosine incorporation on the matrix and to evaluate the relationship between the loading of matrices with 3-chloro-L-tyrosine and the structure of the targets as well as the HPLC purity of the crude detached material.

\section{Conflict of Interests}

The authors declare no conflict of interests.

\section{Acknowledgments}

This study has been supported by AIPRAS Onlus (Associazione Italiana per la Promozione delle Ricerche sull'Ambiente e la Saluta umana). The authors thank CIMCF (Centro di Metodologie Chimico-Fisiche) and Università degli Studi di Napoli "Federico II" for the MS and NMR facilities. They also acknowledge Tecno Bios for grants in support of this investigation.

\section{References}

[1] T. Aboul-Fadl, "Antisense oligonucleotides: the state of the art," Current Medicinal Chemistry, vol. 12, no. 19, pp. 2193-2214, 2005.

[2] S. T. Crooke, "Progress in antisense technology," Annual Reviews of Medicine, vol. 55, pp. 61-95, 2004.

[3] N. M. Dean and C. F. Bennett, "Antisense-oligonucleotidebased therapeutics for cancer," Oncogene, vol. 22, pp. 90879096, 2003.
[4] H. Grosshans and W. Filipowicz, "Molecular biology: the expanding world of small RNAs," Nature, vol. 451, pp. 414-416, 2008.

[5] D. R. Corey, "RNA learns from antisense," Nature Chemical Biology, vol. 3, pp. 8-11, 2007.

[6] J. F. Lee, G. M. Stovall, and A. D. Ellington, "Aptamer therapeutics advance," Current Opinion in Chemical Biology, vol. 10, pp. 282-289, 2006.

[7] T. Da Ros, G. Spalluto, M. Prato, T. Saison-Behmoaras, A. Boutorine, and B. Cacciari, "Oligonucleotides and oligonucleotide conjugates: a new approach for cancer treatment," Current Medicinal Chemistry, vol. 12, no. 1, pp. 71-88, 2005.

[8] E. Uhlmann and J. Vollmer, "Recent advances in the development of immunostimulatory oligonucleotides," Current Opinion in Drug Discovery and Development, vol. 6, no. 2, pp. 204217, 2003.

[9] E. De Clercq, "Highlights in the discovery of antiviral drugs: a personal retrospective," The Journal of Medicinal Chemistry, vol. 53, pp. 1438-1450, 2010.

[10] Y. Richter and B. Fischer, "Nucleotides and inorganic phosphates as potential antioxidants," Journal of Biological Inorganic Chemistry, vol. 11, pp. 1063-1074, 2006.

[11] C. Simons, Nucleoside Mimetics: Their Chemistry and Biological Properties, Gordon and Breach Science, Singapore, 2001.

[12] N. Usman and L. M. Blatt, "Nuclease-resistant synthetic ribozymes: developing a new class of therapeutics," Journal of Clinical Investigation, vol. 106, no. 10, pp. 1197-1202, 2000.

[13] X. Tan, C. K. Chu, and F. D. Boudinot, "Development and optimization of anti-HIV nucleoside analogs and prodrugs: a review of their cellular pharmacology, structure-activity relationships and pharmacokinetics," Advanced Drug Delivery Reviews, vol. 39, no. 1-3, pp. 117-151, 1999.

[14] T. S. Mansour and R. Storer, "Antiviral nucleosides," Current Pharmaceutical Design, vol. 3, pp. 227-264, 1997.

[15] J. Balzarini, "Metabolism and mechanism of antiretroviral action of purine and pyrimidine derivatives," Pharmacy World and Science, vol. 16, no. 2, pp. 113-126, 1994.

[16] D. M. Huryn and M. Okabe, "AIDS-Driven nucleoside chemistry," Chemical Reviews, vol. 92, pp. 1745-1768, 1992.

[17] S. L. Chang, G. W. Griesgraber, P. J. Southern, and C. R. Wagner, 'Amino acid phosphoramidate monoesters of 3'-azido3'-deoxythymidine: relationship between antiviral potency and intracellular metabolism," The Journal of Medicinal Chemistry, vol. 44, no. 2, pp. 223-231, 2001.

[18] S. C. Tobias and R. F. Borch, "Synthesis and biological studies of novel nucleoside phosphoramidate prodrugs," The Journal of Medicinal Chemistry, vol. 44, no. 25, pp. 4475-4480, 2001.

[19] C. McGuigan, R. N. Pathirana, N. Mahmood, K. G. Devine, and A. J. Hay, "Aryl phosphate derivatives of AZT retain activity against HIV1 in cell lines which are resistant to the action of AZT," Antiviral Research, vol. 17, no. 4, pp. 311-321, 1992.

[20] W. Zhou, S. Upendran, A. Roland, Y. Jin, and R. P. Iyer, "Nucleotide libraries as a source of biologically relevant chemical diversity: solution-phase synthesis," Bioorganic and Medicinal Chemistry Letters, vol. 10, no. 11, pp. 1249-1252, 2000.

[21] Y. Jin, A. Roland, W. Zhou, M. Fauchon, J. Lyaku, and R. P. Iyer, "Synthesis and antiviral evaluation of nucleic acid-based (NAB) libraries," Bioorganic and Medicinal Chemistry Letters, vol. 10, no. 17, pp. 1921-1925, 2000.

[22] L. De Napoli, G. Di Fabio, J. D’Onofrio, and D. Montesarchio, "An efficient solid phase synthesis of 5'-phosphodiester and 
phosphoramidate monoester nucleoside analogues," Chemical Communications, no. 20, pp. 2586-2588, 2005.

[23] M. Gaglione, N. Potenza, G. Di Fabio et al., "Tuning RNA interference by enhancing siRNA/PAZ recognition," ACS Medicinal Chemistry Letters, vol. 4, no. 1, pp. 75-78, 2012.

[24] L. Moggio, L. De Napoli, B. Di Blasio et al., "Solid-phase synthesis of cyclic PNA and PNA-DNA chimeras," Organic Letters, vol. 8, no. 10, pp. 2015-2018, 2006.

[25] G. Di Fabio, G. Malgieri, C. . Isernia et al., "Novel synthetic strategy for monosubstituted cyclodextrin derivatives," Chemical Communication, vol. 48, pp. 3875-3877, 2012.

[26] S. Booth, P. H. H. Hermkens, H. C. J. Ottenheijm, and D. Rees, "Solid-phase organic reactions III: a review of the literature Nov 96-Dec 97," Tetrahedron, vol. 54, pp. 15385-15443, 1998.

[27] S. Kobayashi, "New methodologies for the synthesis of compound libraries," Chemical Society Reviews, vol. 28, pp. 1-15, 1999.

[28] F. Balkenhohl, C. von dem Bussche-Huennefeld, A. Lansky, and C. Zechel, "Combinatorial synthesis of small organic molecules," Angewandte Chemie International Edition, vol. 35, pp. 2288-2337, 1996.

[29] P. A. Tempest and R. W. Armstrong, "Cyclobutenedione derivatives on solid support: toward multiple core structure libraries," Journal of the American Chemical Society, vol. 119, pp. 76077608, 1997.

[30] H. Lönnberg, "Solid-phase synthesis of oligonucleotide conjugates useful for delivery and targeting of potential nucleic acid therapeutics," Bioconjugate Chemistry, vol. 20, pp. 1065-1094, 2009.

[31] P. Virta, J. Katajisto, T. Niittymäki, and H. Lönnberg, "Solidsupported synthesis of oligomeric bioconjugates," Tetrahedron, vol. 59, pp. 5137-5174, 2003.

[32] D. A. Stetsenko and M. J. Gait, "A convenient solid-phase method for synthesis of 3'-conjugates of oligonucleotides," Bioconjugate Chemistry, vol. 12, no. 4, pp. 576-586, 2001.

[33] D. L. McMinn, T. J. Matray, and M. M. Greenberg, "Efficient solution phase synthesis of oligonucleotide conjugates using protected biopolymers containing 3'-terminal alkyl amines," Journal of Organic Chemistry, vol. 62, no. 21, pp. 7074-7075, 1997.

[34] J. D. Kahl, D. L. McMinn, and M. M. Greenberg, "Highyielding method for on-column derivatization of protected oligodeoxynucleotides and its application to the convergent synthesis of 5,3'-bis-conjugates," Journal of Organic Chemistry, vol. 63, no. 15, pp. 4870-4871, 1998.

[35] J. D’Onofrio, M. De Champdoré, L. De Napoli, D. Montesarchio, and G. Di Fabio, "Glycomimetics as decorating motifs for oligonucleotides: solid-phase synthesis, stability, and hybridization properties of carbopeptoid- oligonucleotide conjugates," Bioconjugate Chemistry, vol. 16, no. 5, pp. 1299-1309, 2005.

[36] E. Alazzouzi, N. Escaja, A. Grandas, and E. Pedroso, "A straightforward solid-phase synthesis of cyclic oligodeoxyribonucleotides," Angewandte Chemie, vol. 36, no. 13-14, pp. 15061508, 1997.

[37] J. D’Onofrio, D. Montesarchio, L. De Napoli, and G. Di Fabio, "An efficient and versatile solid-phase synthesis of 5'- and 3'conjugated oligonucleotides," Organic Letters, vol. 7, pp. 49274930, 2005.

[38] L. De Napoli, G. Di Fabio, J. D’Onofrio, and D. Montesarchio, "New nucleoside-based polymeric supports for the solid phase synthesis of ribose-modified nucleoside analogues," Synlett, no. 11, pp. 1975-1979, 2004.
[39] M. de Champdoré, L. De Napoli, G. Di Fabio, A. Messere, D. Montesarchio, and G. Piccialli, "New nucleoside based solid supports. Synthesis of 5,3'-derivatized thymidine analogues," Chemical Communication, pp. 2598-2599, 2001.

[40] G. Di Fabio, A. De Capua, L. De Napoli et al., "A new strategy for the solid-phase synthesis of glycoconjugate biomolecules," Synlett, no. 3, pp. 341-344, 2001.

[41] E. Kaiser, R. L. Colescott, C. D. Bossinger, and P. I. Cook, "Color test for detection of free terminal amino groups in the solidphase synthesis of peptides," Analytical Biochemistry, vol. 34, no. 2, pp. 595-598, 1970.

[42] P. W. Davis and S. A. Osgood, "A new method for introducing amidate linkages in oligonucleotides using phosphoramidite chemistry," Bioorganic and Medicinal Chemistry Letters, vol. 9, no. 18, pp. 2691-2692, 1999.

[43] F. Eckstein, Oligonucleotides and Analogues: A Practical Approach, IRL Press, Oxford, UK, 1991. 

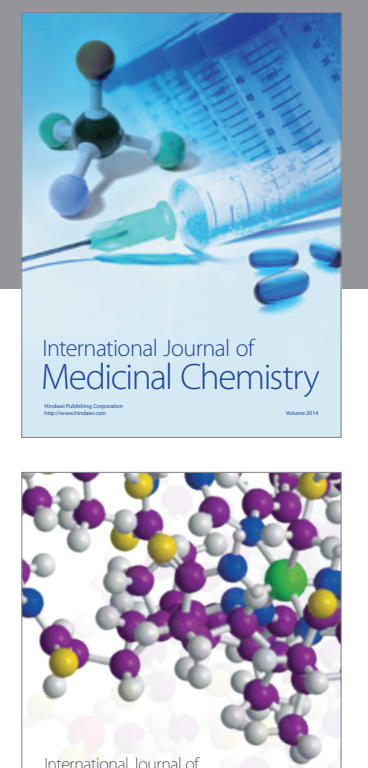

\section{Carbohydrate} Chemistry

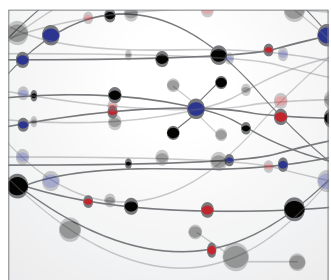

The Scientific World Journal
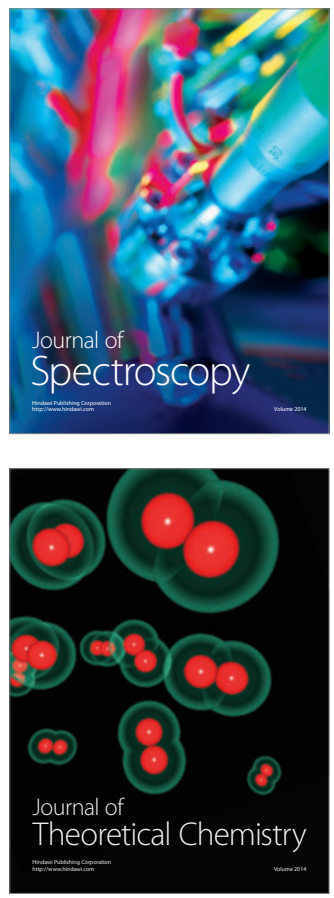
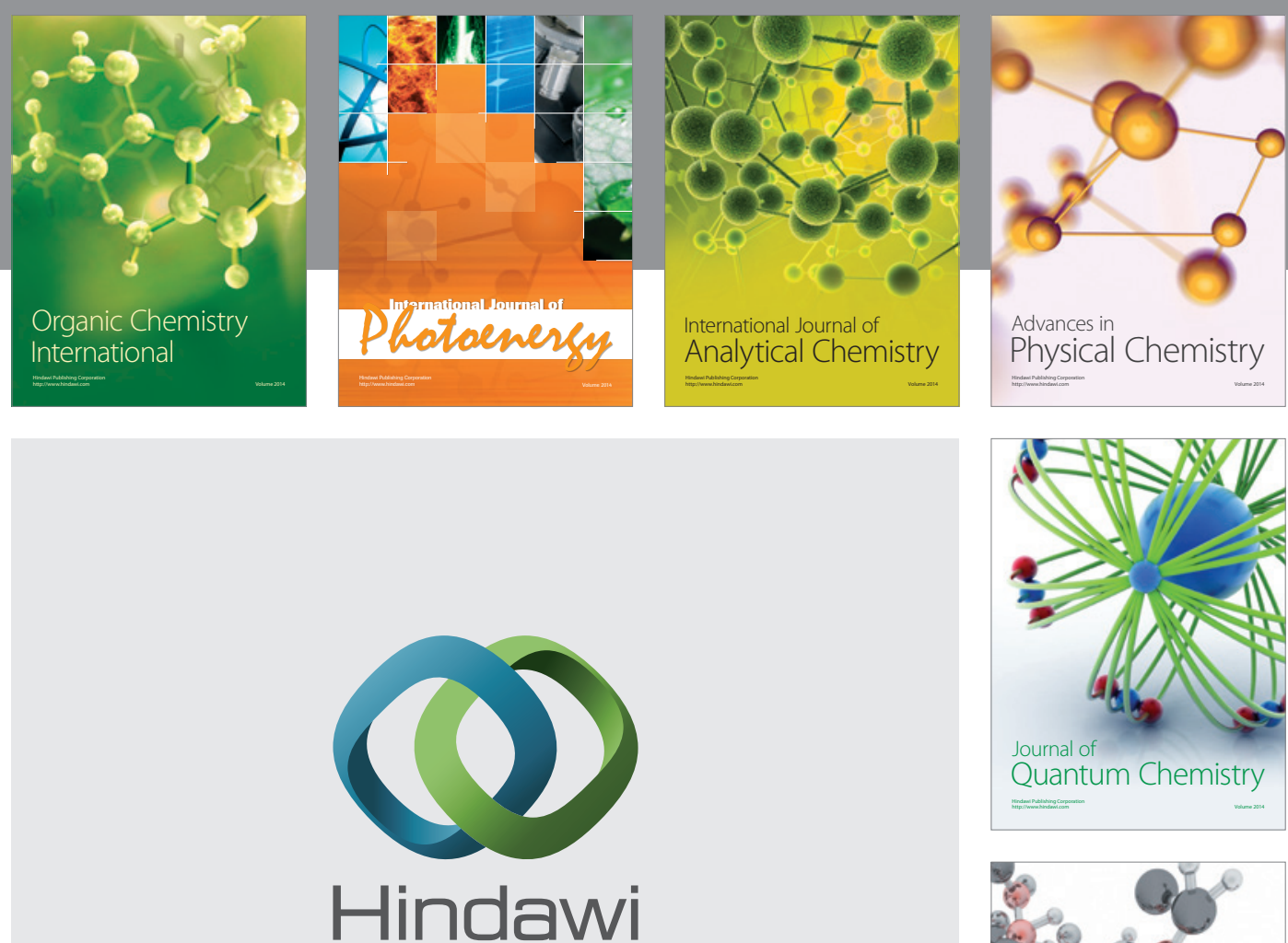

Submit your manuscripts at

http://www.hindawi.com

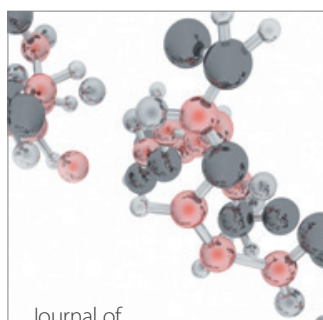

Analytical Methods

in Chemistry

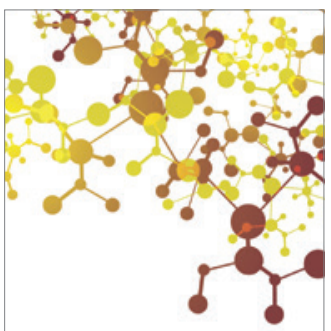

Journal of

Applied Chemistry

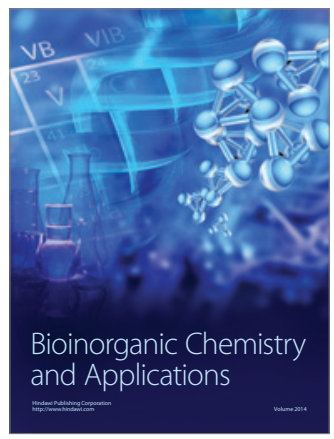

Inorganic Chemistry
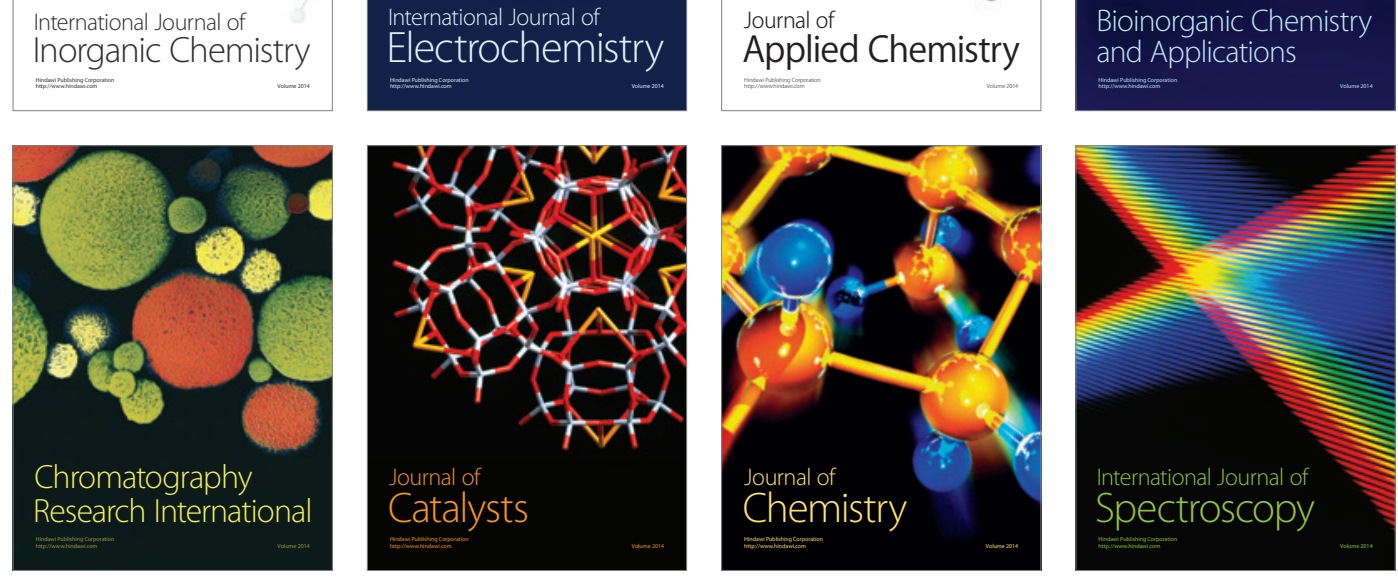